\title{
Efficient biosynthesis of ethyl (R)-4-chloro- 3-hydroxybutyrate using a stereoselective carbonyl reductase from Burkholderia gladioli
}

Xiang Chen ${ }^{1,2}$, Zhi-Qiang Liu ${ }^{1,2}$, Chao-Ping Lin ${ }^{1,2}$ and Yu-Guo Zheng ${ }^{1,2^{*}}$

\begin{abstract}
Background: Ethyl (R)-4-chloro-3-hydroxybutyrate ((R)-CHBE) is a versatile chiral precursor for many pharmaceuticals. Although several biosynthesis strategies have been documented to convert ethyl 4-chloro-3-oxobutanoate (COBE) to (R)-CHBE, the catalytic efficiency and stereoselectivity are still too low to be scaled up for industrial applications. Due to the increasing demand of $(R)-C H B E$, it is essential to explore more robust biocatalyst capable of preparing (R)-CHBE efficiently.

Results: A stereoselective carbonyl reductase toolbox was constructed and employed into the asymmetric reduction of COBE to (R)-CHBE. A robust enzyme designed as BgADH3 from Burkholderia gladioli CCTCC M 2012379 exhibited excellent activity and enantioselectivity, and was further characterized and investigated in the asymmetric synthesis of (R)-CHBE. An economical and satisfactory enzyme-coupled cofactor recycling system was created using recombinant Escherichia coli cells co-expressing BgADH3 and glucose dehydrogenase genes to regenerate NADPH in situ. In an aqueous/octanol biphasic system, as much as $1200 \mathrm{mmol}$ COBE was completely converted by using substrate fed-batch strategy to afford (R)-CHBE with $99.9 \%$ ee at a space-time yield per gram of biomass of $4.47 \mathrm{mmol} \cdot \mathrm{L}^{-1} \cdot \mathrm{h}^{-1} \cdot \mathrm{g} \mathrm{DCW}{ }^{-1}$.

Conclusions: These data demonstrate the promising of $B g A D H 3$ in practical synthesis of (R)-CHBE as a valuable chiral synthon. This study allows for the further application of BgADH3 in the biosynthesis of chiral alcohols, and establishes a preparative scale process for producing (R)-CHBE with excellent enantiopurity.
\end{abstract}

Keywords: Burkholderia gladioli, Carbonyl reductases, Ethyl 4-chloro-3-oxobutanoate, Ethyl (R)-4-chloro-3-hydroxybutyrate, Co-expression

\section{Background}

Stereoselective carbonyl reductases (E.C. 1.1.1.x; SCRs) are nicotinamide cofactor-dependent enzymes capable of catalyzing the reversible redox reaction between alcohols and aldehydes/ketones. During the past decade, SCRs have been considerably applied to the synthesis of chiral pharmaceutical intermediates, including anticholesterol drugs [1, 2], $\beta$-lactams antibiotics [3], anticancer drugs

\footnotetext{
* Correspondence: zhengyg@zjut.edu.cn

${ }^{1}$ Key Laboratory of Bioorganic Synthesis of Zhejiang Province, College of Biotechnology and Bioengineering, Zhejiang University of Technology, Hangzhou 310014, China

${ }^{2}$ Engineering Research Center of Bioconversion and Biopurification of the Ministry of Education, Zhejiang University of Technology, Hangzhou 310014, China
}

[4], and other important drugs [5]. However, the scaleup of SCR-catalyzed reactions were restricted due to the limited commercially available SCRs, narrow substrate specificity, expensive cofactor dependency, and substrate insolubility.

Ethyl $(R)$-4-chloro-3-hydroxybutyrate $((R)$-CHBE) is a synthetic strategies for optically active CHBE were developed, wherein the enzymatic asymmetric synthesis is the most promising way. Although various biocatalysts have been found to give $(S)$-CHBE [1, 2, 9-13], $(R)$-isomer is in great demand yet less attainable. Since then, several 
microorganisms and enzymes capable of converting ethyl 4-chloro-3-oxobutanoate (COBE) to ( $R$ )-CHBE have been documented, including gox2036 from Gluconobacter oxydans [14], AKRs from Sporobolomyces salmonicolor and Lodderomyces elongisporus [15-17], and a reductase from Bacillus sp. ECU0013 [18]. However, all of them suffer from impediment such as low substrate concentration, unsatisfactory stereoselectivity, or high substrate/catalyst (S/C) ratio. These shortcomings hindered their applications in the industrial synthesis of $(R)$-CHBE. Exploring more robust SCRs with the ability to prepare enantioenriched $(R)$-CHBE efficiently is thus of great interest.

Herein, we designed and implemented two strategies for identifying novel SCRs, and constructed an enzyme toolbox to screen a robust SCR that can biotransform $\mathrm{COBE}$ to $(R)-\mathrm{CHBE}$. As the promising SCR, BgADH3 from Burkholderia gladioli CCTCC M 2012379 was selected for further study. The substrate spectrum of $B g A D H 3$ was evaluated toward varied aryl ketones and ketoesters. Furthermore, the practical applicability of $B g A D H 3$ was investigated in the asymmetric synthesis of $(R)$-CHBE using Escherichia coli cells co-expressing $B g \mathrm{ADH} 3$ and a glucose dehydrogenase (GDH). Since the substrate was poorly soluble and unstable in aqueous environments, biphasic system was established using substrate fed-batch strategy to solve this issue. To our knowledge, this is the first report of SCR from B. gladioli subjected to the asymmetric synthesis of enantioenriched $(R)$-CHBE in aqueous/octanol biphasic system.

\section{Results}

\section{Identification and screening of SCRs}

Strain B. gladioli CCTCC M 2012379 isolated from soil samples exhibited activity for catalyzing COBE to $(R)$ CHBE (Additional file 1: Table S1). Genome hunting and data mining strategies were selected to discovering robust SCRs from CCTCC M 2012379. Based on bioinformatics analysis of sequence-similarity with gox2036 [14], which is a known NADH-dependent SCR giving enantiopure $(R)$ CHBE. 35 candidates were cloned or synthesized, and heterologously overexpressed in E. coli BL21 (DE3), wherein $B g A D H 3$ displayed high activity toward COBE and afforded $(R)$-CHBE (Additional file 2: Table S2). Sequence analysis indicated that the $B g A D H 3$ gene contained an open reading frame with 1011 bp encoding a 336 amino-acid protein, in which the conserved NADPbinding motiff $\mathrm{T}_{97} \mathrm{G}_{98} \mathrm{XXXG}_{102} \mathrm{XG}_{104}$ and key catalytic residues $\mathrm{N}_{202} \mathrm{~S}_{228} \mathrm{Y}_{241} \mathrm{~K}_{245}$ were found (Additional file 3: Figure S1). The recombinant $B g A D H 3$ with $\mathrm{His}_{6}$-tag mainly presented in the soluble fraction was purified through nickel chelating affinity chromatography [19]. As shown in Fig. 1, the BgADH3 was not homogeneous, and the estimated molecular mass was around $37 \mathrm{kDa}$, in accordance with its theoretical value $(37.3 \mathrm{kDa})$. The

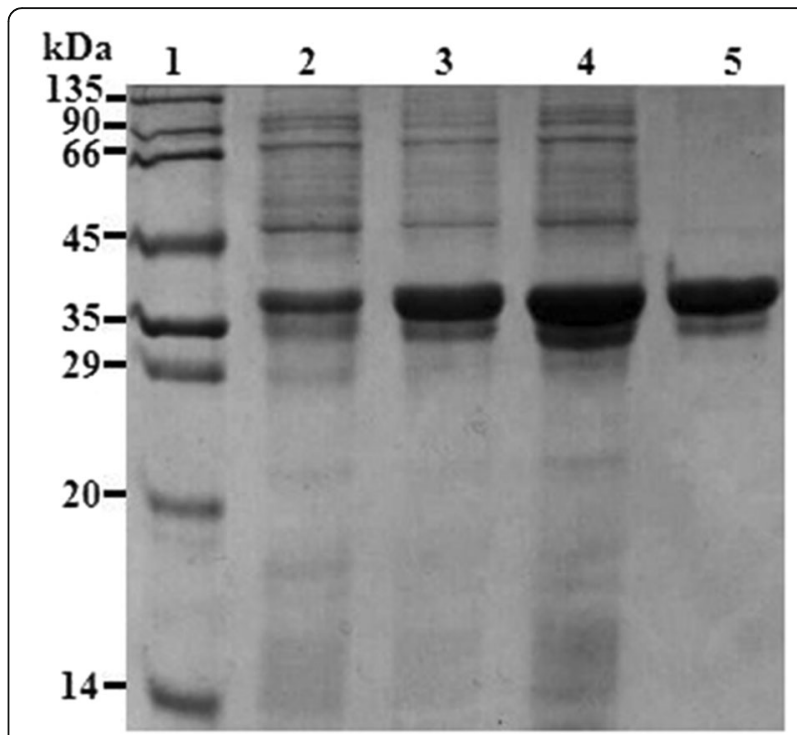

Fig. 1 SDS-PAGE analysis of BgADH3. Lane 1, molecular mass standard; Lane 2, E. coli BL21 (DE3)/pET28b-BgADH3 without IPTG induction; Lane 3, crude extract; Lane 4, soluble fraction; Lane 5, purified BgADH3

molecular mass of native $B g A D H 3$ determined on the Discovery BIO GFC 150 column suggested that the quaternary structure of $\mathrm{BgADH} 3$ was dimer.

\section{Biochemical characterization of $\mathrm{BgADH} 3$}

To investigate the effect of $\mathrm{pH}$ on the activity and stability of $B g \mathrm{ADH} 3$, different $\mathrm{pH}$ values ranging from 3.5 to 10.5 were tested. As a result, a bell-shaped $\mathrm{pH}$ profile was observed and the maximum activity was found at pH 6.5 (Fig. 2a). Remarkably, the recombinant BgADH3 is highly stable between $\mathrm{pH} 5.0$ and 9.0 (Fig. 2b). The effect of temperature on $\mathrm{BgADH} 3$ activity was assessed by measuring activity at $25-65{ }^{\circ} \mathrm{C}$. The optimum temperature occurred at $40{ }^{\circ} \mathrm{C}$ (Fig. 2c). Thermostability of $\mathrm{BgADH} 3$ was evaluated at temperatures of $25,35,45$, 55 , and $65{ }^{\circ} \mathrm{C}$, respectively. Half-life time of $47 \mathrm{~h}$ was found at $45^{\circ} \mathrm{C}$. However, the enzyme was labile at higher temperatures $\left(55\right.$ and $65{ }^{\circ} \mathrm{C}$ ) (Fig. 2d). The presence of $\mathrm{Ca}^{2+}, \mathrm{Co}^{2+}, \mathrm{Cu}^{2+}, \mathrm{Fe}^{3+}, \mathrm{Zn}^{2+}$, and $\mathrm{Mg}^{2+}$ slightly enhanced the activity of $\mathrm{BgADH} 3$, whereas $\mathrm{Ag}^{+}$inhibited the activity of the enzyme with a loss of $75 \%$ (Additional file 4: Table S3). When the metal-chelating agent EDTA$\mathrm{Na}_{2}$ was added, the residual activity of $B g A D H 3$ was maintained intact $(99 \%)$. Cofactor preference of $B g A D H 3$ was evaluated using $\mathrm{COBE}$ as substrate and the result was given in Table 1 . The purified BgADH3 displayed specific activities for the asymmetric reduction of COBE using both NADH and NADPH as cofactors. Although the $K_{\mathrm{mNADPH}}$ value $(0.081 \mathrm{mM})$ of $B g \mathrm{ADH} 3$ was slightly greater than that toward NADH $(0.058 \mathrm{mM})$, 

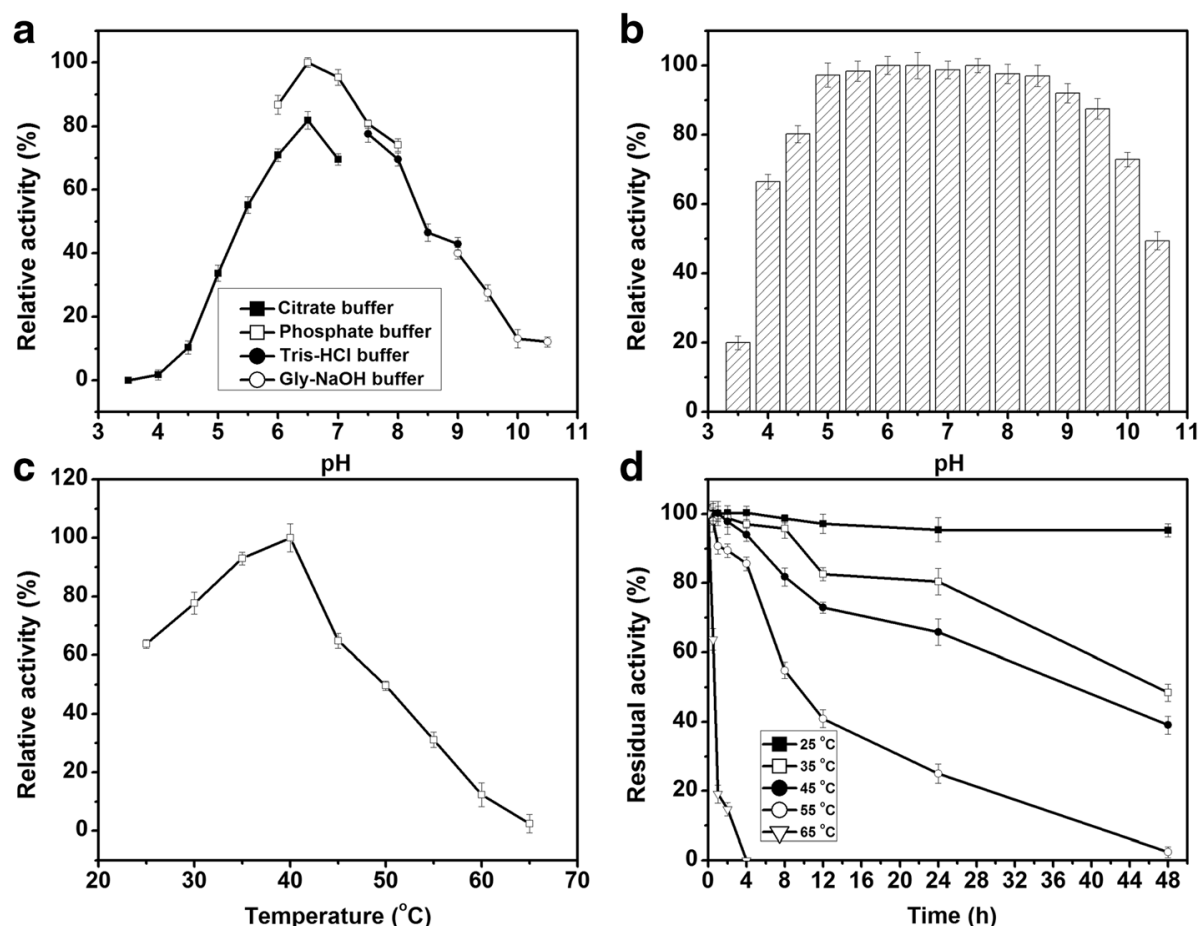

Fig. 2 Effects of $\mathrm{pH}$ and temperature on the activity and stability of $B g A D H 3$. a Optimal pH. b pH stability. c Optimal temperature. d Thermostability. Reaction conditions: COBE $(50 \mathrm{mM}), \mathrm{NADPH}(0.5 \mathrm{mM})$, and purified $\mathrm{BgADH} 3\left(0.1 \mathrm{mg} \mathrm{mL}^{-1}\right)$. The activities were determined after the addition of NADPH for $2 \mathrm{~min}$. All reactions were performed in triplicate

the overall catalytic efficiency $\left(k_{\mathrm{cat}} / K_{\mathrm{m}}\right)$ for NADPH was approximately 2 -fold enhancement compared to that against NADH.

\section{Effects of organic solvents}

A series of hydrophobic solvents were selected to assess their effects on BgADH3 activity and histograms representing the residual activities were arrayed in accordance with the increasing $\log P$ values (Fig. 3). $B g A D H 3$ activity was roughly correlated with the log $P$ values of the corresponding solvents, except for dichloromethane, which strongly inhibited the enzyme activity. High activity was observed in the present of hydrophobic solvents with high $\log P$ value, such as octanol (91\%), cyclohexane (94\%), $n$-hexane (95\%), $n$-heptane (102\%), and iso-octane (99\%). Similarly, the effect of the hydrophobicity of the solvents on

Table 1 Apparent kinetic parameters of $\mathrm{BgADH}^{\mathrm{a}}$

\begin{tabular}{lll}
\hline Substrate & $\mathrm{NADH}$ & $\mathrm{NADPH}$ \\
\hline$K_{\mathrm{m}}(\mathrm{mM})$ & 0.058 & 0.081 \\
$V_{\max }\left(\mu \mathrm{mol} \mathrm{min}{ }^{-1} \mathrm{mg}^{-1}\right)$ & 3.4 & 9.1 \\
$k_{\text {cat }}\left(\mathrm{s}^{-1}\right)$ & 3.97 & 10.6 \\
$k_{\text {cat }} / K_{\mathrm{m}}\left(\mathrm{mM}^{-1} \mathrm{~s}^{-1}\right)$ & 68.3 & 131 \\
\hline
\end{tabular}

Reaction conditions: substrate COBE $(50 \mathrm{mM}), \mathrm{NADH}$ or NADPH $(0.01-0.5 \mathrm{mM})$, purified $B g A D H 3\left(0.1 \mathrm{mg} \mathrm{mL}^{-1}\right), \mathrm{pH} 6.5$, and $40^{\circ} \mathrm{C}$ the retention of $B g \mathrm{ADH} 3$ stability was investigated. Satisfactory results were obtained in the present of methyl tert-butyl ether (MTBE), butyl acetate, octanol, iso-octane, and $n$-heptane, wherein the highest stability was observed in the presence of MTBE (100\%).

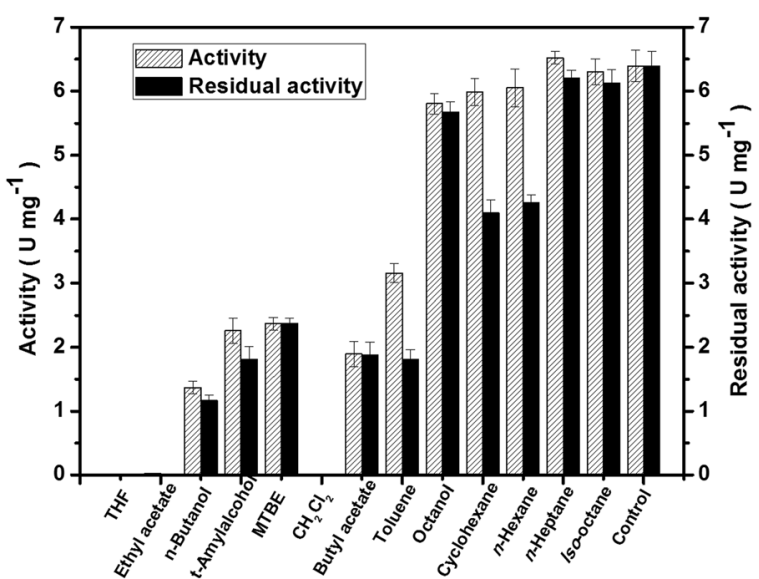

Fig. 3 Effect of organic solvents on the activity and stability of recombinant $B g A D H 3$. The activities were measured using $C O B E$ as substrate under the standard assay protocol. Stability was determined by measuring the residual activities after incubation with organic solvents at $30^{\circ} \mathrm{C}$ for $30 \mathrm{~min}$. The activity in the absence of organic solvent was taken as control. THF, tetrahydrofuran; MTBE, methyl tert-butyl ether; $\mathrm{CH}_{2} \mathrm{Cl}_{2}$, dichloromethane 


\section{Substrate specificity and stereoselectivity}

Specific activity was determined rapidly by using spectrophotometric standard assay described above and the stereoselectivity was evaluated in aqueous phosphate buffer by adding cosubstrate. As shown in Table 2, BgADH3 were active on all the tested aryl ketones and ketoesters, and exhibited dramatically high activity toward 4'-fluoroacetophenone 6, 3,5'-bis(trifluoromethyl) acetophenone 7, and COBE 12. In contrast, substrate 4, 5, 8, 15, 16, and 17 significantly diminished the activity of BgADH3. Notably, excellent stereoselectivity of $B g A D H 3$ was also observed for most of the tested substrates, resulting in the corresponding chiral alcohols with $>99 \%$ ee (Additional file 5: Table S4). BgADH3 generally exhibited $S$ preference, but the corresponding bioproducts with $R$ configuration were obtained toward substrates $\mathbf{1 2 - 1 5}$ and $\mathbf{1 7}$.

\section{Co-expression of $\mathrm{BgADH} 3$ and GDH genes}

The $B g A D H 3$ gene and GDH gene (786 bp) encoding 261-amino acids were introduced into the MCSI and MCSII sites of pCDFDuet-1 vector (Fig. 4a). After induced by IPTG, the recombinant BgADH3 and GDH protein were successfully expressed in the same $E$. coli cell. The molecular weights of $37 \mathrm{kDa}$ for $B g A D H 3$ and $28 \mathrm{kDa}$ for GDH was observed in the sodium dodecyl sulfate polyacrylamide gel electrophoresis (SDS-PAGE) (Fig. 4b), which indicated that the expressed products are consistent with the predicted proteins.

\section{Asymmetric synthesis of $(R)$-CHBE in aqueous-organic solvent system \\ Screening of organic phase}

To screen an appropriate organic phase in the biphasic system for $(R)$-CHBE production by using co-expression strain $E$. coli/pCDFDuet-1-BgADH3-GDH, n-butanol, tert-amylalcohol, MTBE, butyl acetate, toluene, and octanol were selected to evaluate the effects on product yield and ee. The result was presented in Table 3. All yields of aqueous-organic solvents systems were below $50 \%$ or less, except for octanol, in which a yield of $86.6 \%$ was obtained. It was noteworthy that reduction of COBE was strongly inhibited in butyl acetate, affording too low yield (12\%). Interestingly, the enantioselectivity was not impaired and maintained $>99 \% e e$ in the presence of all the tested organic solvents.

\section{Optimization of reaction conditions}

To improve the asymmetric reduction of COBE to $(R)$ CHBE by using co-expression $E$. coli, different reaction conditions were further investigated. As shown in Fig. 5a, it was found that the yield of $(R)$-CHBE was significantly improved when the glucose/COBE $(\mathrm{mmol} / \mathrm{mmol})$ ratio was increased to 3 , and then was clearly diminished when the ratio was over 8 . To effectively synthesize $(R)$ -
$\mathrm{CHBE}$, the amount of $\mathrm{NADP}^{+}$was also optimized. The highest yield was obtained using a $\mathrm{NADP}^{+} / \mathrm{COBE}$ $(\mu \mathrm{mol} / \mathrm{mmol})$ ratio of 1.0 and a huge excess of NADP ${ }^{+}$ was not necessary (Fig. 5b). The maximum level of yield was found at $30{ }^{\circ} \mathrm{C}$ and $\mathrm{pH} 6.5$ (Fig. $5 \mathrm{c}$ and d). An increased production of $(R)$-CHBE was observed as the cell dosage was raised from 0.02 to $0.04 \mathrm{~g} \mathrm{DCW}$. When the cell dosage was excess $0.04 \mathrm{~g}$ DCW, the yield of $(R)$ CHBE was not increased significantly (Fig. 5e). Keeping constant the $\mathrm{S} / \mathrm{C}(\mathrm{mmol} / \mathrm{g} \mathrm{DCW})$ ratio of 150 , different amount of COBE were further estimated. The yield of (R)-CHBE was significantly decreased when more than $24 \mathrm{mmol}$ of the substrate was added (Fig. 5f). Based on the above results, the optimum reaction conditions in $20 \mathrm{~mL}$ system were obtained: COBE $24 \mathrm{mmol}$, glucose $72 \mathrm{mmol}, \mathrm{NADP}^{+} 24 \mu \mathrm{mol}$, cell dosage $0.16 \mathrm{~g} \mathrm{DCW}$, $\mathrm{pH} 6.5$, and $30{ }^{\circ} \mathrm{C}$.

\section{Substrate fed-batch strategy and preparative scale}

The reaction was performed in a water/octanol biphasic system with a total of $1200 \mathrm{mmol}$ COBE addition that was fed in three steps, during which the resulting gluconic acid was neutralized with $2 \mathrm{M} \mathrm{NaOH}$ to maintain an initial $\mathrm{pH}$ of 6.5. As shown in Fig. 6, at $20 \mathrm{~h}, 1101.6 \mathrm{mmol}$ of $(R)$ $\mathrm{CHBE}$ was produced with a satisfactory enantiomeric purity of $99.9 \% e e$ and the remaining COBE substrate was not detectable. After normal downstream processing, the desired chiral alcohol product was obtained with a yield of $91.8 \%$. To further confirm the structure and configuration of the final product, NMR, MS, and optical rotation were performed. ${ }^{1} \mathrm{H}$ NMR (400 MHz, $\mathrm{CDCl}_{3}$ ): $\delta 4.3-4.28(\mathrm{~m}$, $1 \mathrm{H}), 4.18(\mathrm{q}, J=7.2 \mathrm{~Hz}, 2 \mathrm{H}), 3.60-3.61(\mathrm{~m}, 2 \mathrm{H}), 3.01(\mathrm{~s}$, $1 \mathrm{H}), 2.57-2.66(\mathrm{~m}, 2 \mathrm{H})$, and $1.24-1.29(\mathrm{~m}, 3 \mathrm{H})$ (Additional file 6: Figure $\mathrm{S} 2) ;{ }^{13} \mathrm{C}$ NMR $\left(126 \mathrm{MHz}, \mathrm{CDCl}_{3}\right): \delta$ 171.76, 67.93, 60.98, 48.12, 38.51, 14.07 (Additional file 6: Figure S3); MS calculated for $\mathrm{C}_{6} \mathrm{H}_{12} \mathrm{ClO}_{3}$ : 167.0, found: $167.2[\mathrm{M}+1] ; \quad[\alpha]_{\mathrm{D}}^{25}=+15.1^{\circ} \quad(\mathrm{c}=20 \mathrm{mg} / \mathrm{mL}$, $\left.\mathrm{CHCl}_{3}\right)\left([\alpha]_{\mathrm{D}}^{23}=+14^{\circ}\right.$ (neat), Sigma-Aldrich).

\section{Discussion}

During the past decade, the efficiency of asymmetrically biocatalytic synthesis catalyzed by SCRs has emerged as an environmentally sustainably alternative to traditional organo- and metallocatalysis due to the inherent high stereoselectivity of the biocatalysts and the mild reaction conditions. However, there are still impeded in their large-scale application due to the limited commercially robust biocatalysts, the narrow substrate specificity and the dependency of expensive cofactor as well as the water-insoluble substrates [20]. With the development of genomics, proteomics, and bioinformatics, genome hunting and data mining have become powerful tools for exploiting novel enzymes [21, 22]. In the present study, on the basis of screening results of microorganisms, and the 
Table 2 Substrate specificity and stereoselectivity of the BgADH3

\begin{tabular}{|c|c|c|c|c|}
\hline \multicolumn{3}{|c|}{ Structure of substrate } & \multirow[t]{2}{*}{ Specific activity $^{\mathrm{a}}$} & \multirow[t]{2}{*}{$e e$ or $d e(\%)^{b}$} \\
\hline \multicolumn{3}{|c|}{ Aryl } & & \\
\hline ket & $\mathrm{R}_{1}$ & $\mathrm{R}_{2}$ & & \\
\hline 1 & $\mathrm{H}$ & $\mathrm{CH}_{3}$ & 3.6 & $S(>99)^{\mathrm{c}}$ \\
\hline 2 & 4'- $-\mathrm{CH}_{3}$ & $\mathrm{CH}_{3}$ & 3.2 & $S(>99)^{\mathrm{c}}$ \\
\hline 3 & $4^{\prime}-\mathrm{OCH}_{3}$ & $\mathrm{CH}_{3}$ & 3.7 & $S(>99)^{\mathrm{d}}$ \\
\hline 4 & 2'- $-\mathrm{OCH}_{3}$ & $\mathrm{CH}_{3}$ & 0.018 & $S(>99)^{\mathrm{d}}$ \\
\hline 5 & $3^{\prime}, 5^{\prime}-\mathrm{OCH}_{3}$ & $\mathrm{CH}_{3}$ & 0.009 & $S(>99)^{\mathrm{d}}$ \\
\hline 6 & $4^{\prime}-\mathrm{F}$ & $\mathrm{CH}_{3}$ & 5.9 & $S(>99)^{\mathrm{c}}$ \\
\hline 7 & $4^{\prime}-\mathrm{CF}_{3}$ & $\mathrm{CH}_{3}$ & 6.1 & $S(>99)^{\mathrm{c}}$ \\
\hline 8 & $3^{\prime}, 5^{\prime}-\mathrm{CF}_{3}$ & $\mathrm{CH}_{3}$ & 0.094 & $S(>99)^{\mathrm{c}}$ \\
\hline 9 & $4^{\prime}-\mathrm{NO}_{2}$ & $\mathrm{CH}_{3}$ & 4.1 & $S(>99)^{\mathrm{d}}$ \\
\hline \multicolumn{2}{|c|}{ Ketoesters } & & & \\
\hline & $\mathrm{R}_{1}$ & $\mathrm{R}_{2}$ & & \\
\hline 10 & $\mathrm{CH}_{3}$ & $\mathrm{CH}_{2} \mathrm{CH}_{3}$ & 0.45 & $S(>99)^{\mathrm{c}}$ \\
\hline 11 & $\mathrm{CH}_{3}$ & $\mathrm{C}\left(\mathrm{CH}_{3}\right)_{3}$ & 1.8 & $S(>99)^{\mathrm{c}}$ \\
\hline 12 & $\mathrm{CH}_{2} \mathrm{Cl}$ & $\mathrm{CH}_{2} \mathrm{CH}_{3}$ & 6.3 & $R(>99)^{\mathrm{c}}$ \\
\hline 13 & $\mathrm{CH}_{2} \mathrm{Br}$ & $\mathrm{CH}_{2} \mathrm{CH}_{3}$ & 2.7 & $R(>99)^{\mathrm{c}}$ \\
\hline 14 & $\mathrm{CF}_{3}$ & $\mathrm{CH}_{2} \mathrm{CH}_{3}$ & 3.2 & $R(96)^{\mathrm{c}}$ \\
\hline 15 & $\mathrm{CH}_{2} \mathrm{Ph}$ & $\mathrm{CH}_{2} \mathrm{CH}_{3}$ & 0.0091 & $R(>99)^{\mathrm{d}}$ \\
\hline 16 & & & 0.0049 & $3 S, 5 R(95)^{\mathrm{d}}$ \\
\hline 17 & & & 0.018 & $3 R, 5 S(93)^{\mathrm{d}}$ \\
\hline
\end{tabular}



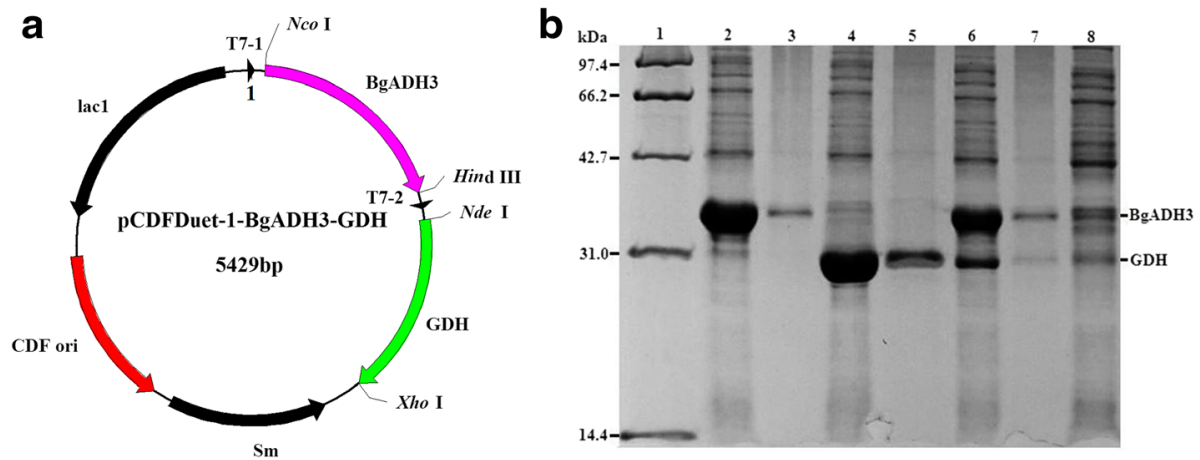

Fig. 4 Schematic presentation of the co-expression plasmid contained BgADH3 and GDH genes and SDS-PAGE analysis. a Structure of the co-expression plasmid pCDFDuet-1-BgADH3-GDH. b SDS-PAGE analysis of recombinant co-expressed protein. Lane 1, protein molecular weight marker; Lane 2, soluble fraction of E. coli/pET28b-BgADH3; Lane 3, precipitate of E. coli/pET28b-BgADH3; Lane 4, soluble fraction of E. coli/pET28b-GDH; Lane 5, precipitate of E. coli/ pET28b-GDH; Lane 6, soluble fraction of E. coli/pCDFDuet-1-BgADH3-GDH; Lane 7, precipitate of E. coli/pCDFDuet-1-BgADH3-GDH; Lane 8, E. coli/pCDFDuet-1-BgADH3-GDH without induction

combination of the BLASTp searching using the reported carbonyl reductase (GenBank accession no. AAW61772.1), a toolbox contained 35 candidates predicted as carbonyl reductases was successfully constructed, and further subjected to the asymmetric synthesis of enantioenriched $(R)$-CHBE.

Optically active $(R)$-CHBE is a useful chiral building block for L-carnitine, a biomolecule capable of modulating the serum oxidation stress and lipid profile [23], and is synthesized through the asymmetrical reduction of COBE. A SCR from G. oxydans $621 \mathrm{H}$ was reported to provide for accessing $(R)$-CHBE, but with low substrate concentration $(6 \mathrm{mM})$ [14]. Using an AKR from $S$. salmonicolor, as much as $268 \mathrm{~g} \mathrm{~L}^{-1}$ of COBE was converted to $(R)$-CHBE yet with moderate enantioselectivity (only $91.7 \% e e)$ [15]. A reductase from Bacillus sp. ECU0013 was capable of producing $(R)$-CHBE with high substrate

Table 3 Screening of organic solvents for biosynthesis of (R)-CHBE

\begin{tabular}{|c|c|c|c|c|c|}
\hline \multirow[t]{2}{*}{ Organic solvent } & \multirow{2}{*}{$\begin{array}{l}\log \\
P^{a}\end{array}$} & \multicolumn{2}{|c|}{ Partition coefficient ${ }^{b}$} & \multirow{2}{*}{$\begin{array}{l}\text { Yield } \\
\text { (\%) }\end{array}$} & \multirow{2}{*}{$\begin{array}{l}e e \\
(\%)\end{array}$} \\
\hline & & COBE & $\mathrm{CHBE}$ & & \\
\hline n-Butanol & 0.839 & $2.6^{\mathrm{C}}$ & $1.8^{c}$ & 37.7 & $>99$ \\
\hline tert-Amylalcohol & 1.094 & $3.3^{c}$ & $2.9^{c}$ & 39.4 & $>99$ \\
\hline MTBE & 1.296 & $8.9^{c}$ & $4.8^{c}$ & 48.1 & $>99$ \\
\hline Butyl acetate & 1.804 & 10.6 & 15.8 & 12.8 & $>99$ \\
\hline Toluene & 2.27 & 21.3 & 2.8 & 44.1 & $>99$ \\
\hline Octanol & 2.876 & 5.3 & 3.8 & 86.6 & $>99$ \\
\hline
\end{tabular}

${ }^{a}$ Calculated using Advanced Chemistry Development (ACD/Labs) Software V11.02

${ }^{\mathrm{b}}$ Partition coefficient is the molar ratio of each compound found in the organic phase to the same compound in the aqueous phase (data from ref. [18, 46, 47]) 'COBE $(73.9 \mu \mathrm{mol})$ and CHBE $(71.2 \mu \mathrm{mol})$ in $0.7 \mathrm{~mL}$ phosphate buffer $(100 \mathrm{mM}$, 6.5) were shaken with organic solvents $(0.7 \mathrm{~mL})$ at $30{ }^{\circ} \mathrm{C}$ in an eppendorf tube. The concentrations of COBE and CHBE in each phase were determined by GC analysis loading (215 $\mathrm{g} \mathrm{L}^{-1}$ ) and enantioselectivity (99.6 \% ee), however, it required high $\mathrm{S} / \mathrm{C}$ and only small-scale was accomplished [18]. In this study, a robust SCR designed as $B g A D H 3$ (GenBank Accession No. AEA63541) from B. gladioli CCTCC M 2012379 demonstrated high catalytic efficiency and excellent enantioselectivity thus was considered as a promising SCR for the asymmetric synthesis of optically active $(R)$-CHBE, accomplishing an economic and environmental balance.

Considering the majority of pairwise similarities between SCR members are in the range of $15-30 \%$, and the presence of conserved NADP-binding motiff TGXXXGXG as well as N-S-Y-K catalytic terads [24], BgADH3 was defined as the 'classical' short-chain dehydrogenases/reductases (SDR). Although the well-known Lactobacillus brevis SDR exhibited strong $\mathrm{Mg}^{2+}$ dependency [25], SDRs generally does not require metal ions. In this case, the metal chelator EDTA did not impact the activity, and most of the tested metal ions did not significantly improved BgADH3 activity, revealing that $B g A D H 3$ is typical of non-metal SDR. Several SCRs have been described capable of oxidizing both NADH and NADPH in the asymmetric reduction [26, 27]. In this study, cofactor preference of $B g A D H 3$ was evaluated using $\mathrm{COBE}$ as substrate, indicating that $\mathrm{BgADH} 3$ was not completely specific to NADH or NADPH as well. Due to the higher catalytic efficiency, NADPH was selected as the cofactor in the reduction of COBE using BgADH3. Notably, the catalytic ability of BgADH3 was approximately 5-fold improvement compared to that found on the literature for gox2036, an NADH-dependent SDR provided access to (R)-CHBE [14].

Enzymes generally require aqueous media in which the hydrophobic substrates are poorly soluble and even unstable. A straightforward solution to this issue might be the application of an aqueous organic solvent system [28, 29]. There are several documented cases in which organic 

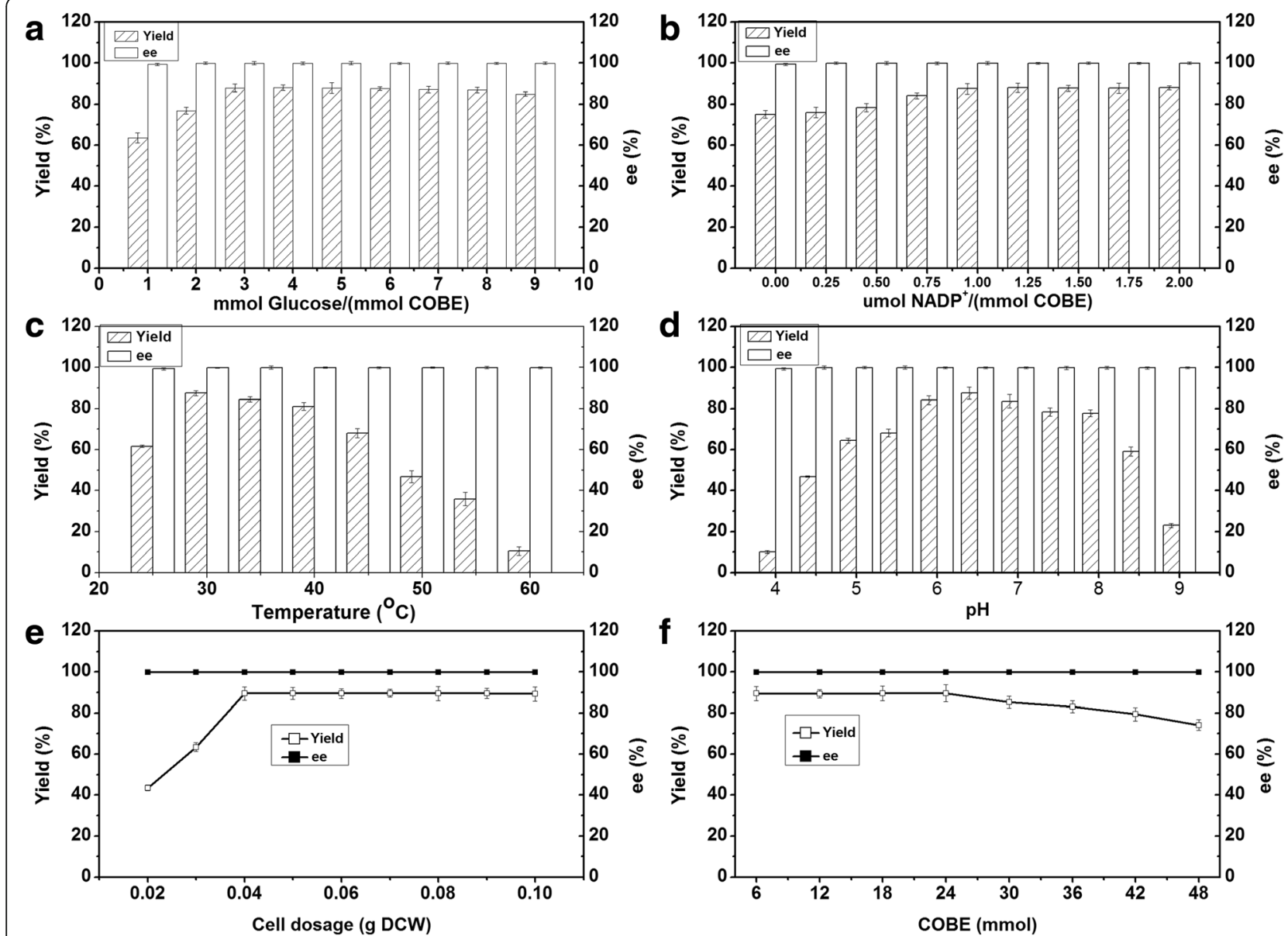

Fig. 5 Effects of glucose concentrations $(\mathbf{a}), \mathrm{NADP}^{+}$concentrations $(\mathbf{b})$, temperature $(\mathbf{c}), \mathrm{pH}(\mathbf{d})$, cell dosage (e), and substrate loading (f) on the biosynthesis of (R)-CHBE using co-expression E. coli cells

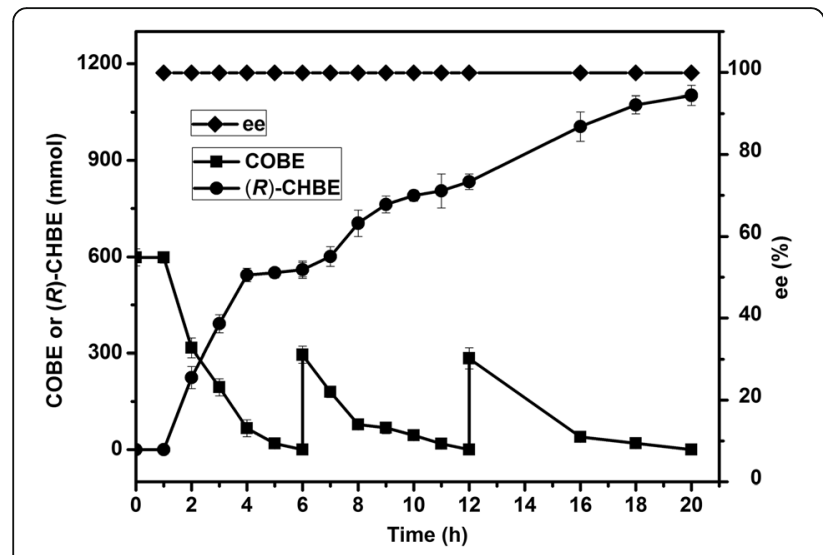

Fig. 6 Production of (R)-CHEB using co-expression E. coli cells in a water/ octanol biphasic system with a substrate fed-strategy. Reduction of COBE using sonicated co-expressed E. coli cells (8 g DCW) was conducted at $30{ }^{\circ} \mathrm{C}$ in $0.5 \mathrm{~L}$ phosphate buffer ( $\left.\mathrm{pH} 6.5\right)$ containing glucose (1800 mmol) and COBE $(600 \mathrm{mmol})$ and $0.5 \mathrm{~L}$ octanol. COBE $(300 \mathrm{mmol})$ together with 3 equiv. glucose were added to the system at $6 \mathrm{~h}$ and $12 \mathrm{~h}$, respectively solvents can affect the enzymatic activity [30-33]. Compared to hydrophobic solvents, hydrophilic ones are usually easier impact the activity due to the greater tendency of stripping tightly bound water in the enzyme molecules [34]. Herein, batteries of water-immiscible solvents were tested for the influence on the activity of $B g A D H 3$. High activity observed in the presence of hydrophobic solvents with high $\log P$ value was consistent with the recent study of organic tolerance of alcohol dehydrogenases [35]. In contrast, the stability of $B g A D H 3$ showed no dependence on the hydrophobicity of solvents. This finding is in agreement with the assumption that solvent functionality is also significance for enzyme deactivation [36]. Thus, it was established that log $P$ was not an adequate parameter to describe the trend of enzyme tolerance to organic solvents. Although BgADH3 exhibited high activity and stability in the presence of cyclohexane, $n$-hexane, $n$-heptane, and iso-octane, COBE and (R)-CHBE exhibited low solubility due to the poor partition coefficient thus were not suitable for the application in aqueous organic solvent system. Butyl acetate has been frequently introduced as the non-aqueous phase in the 
reduction of $\mathrm{COBE}[2,9]$, however, $\mathrm{BgADH} 3$ was strongly inactivated in this solvent. In this case, octanol was eventually chosen as the organic phase in the biphasic system.

Different position and size of the substituents in carbonyl compounds play an critical role in the enzyme activity [37]. With regard to acetophenone derivatives, the ortho-substituted group (4) or multi-substitution (5 and 8) reduced the $B g A D H 3$ activity due to the steric hindrance effects on the hydrogen attack from NADPH to the carbonyl group. Likewise, the bulky substituents in ketoesters adjacent to the carbonyl group also have negative effects. $B g A D H 3$ generally obeys Prelog's rule with $S$ preference by the hydride transfer from the cofactor to the Re-face of the carbonyl group during the enzymatic reductions, similar to the majority of known SCRs [14]. The inverted stereochemical assignment observed toward 12-14 and 17 was explained by a higher Cahn-Ingold-Prelog priority in the smaller side of substrate than the large one, thus still followed the Prelog's rule of hydride delivery. However, the reduction of $\mathbf{1 5}$ catalyzed by $B g \mathrm{ADH} 3$ also afforded the $(R)$-enantiomer, suggesting that bulky substituent might affect the configuration of the corresponding alcohol.

Although the upscale application of SCRs was impeded by the requirement for expensive cofactors such as $\mathrm{NAD}(\mathrm{P})^{+} / \mathrm{NAD}(\mathrm{P}) \mathrm{H}$, enzyme-coupled and substratecoupled cofactor recycling strategies have been developed for surmounting this challenge [38-40]. Compared to the substrate-coupled cofactor recycling with reversibility and poor thermodynamic driving force, enzymecoupled cofactor regeneration exhibited more efficient and inexpensive. In this study, GDH from Exiguobacterium sibiricum 255-15 (GenBank: ACB59697.1) and glucose was successfully coupled with $B g A D H 3$ in the biosynthesis of $(R)$-CHBE. Expressing SCR and GDH in same cell is the possibility to avoid using an additional expensive cofactor when performing the biotransformation with high substrate loading [41-43]. Herein, the $\mathrm{BgADH} 3$ and GDH genes were introduced into the pCDFDuet-1 vector to construct the co-expressed plasmid pCDFDuet-1-BgADH3-GDH and strain E. coli/pCDFDuet$1-B g A D H 3-G D H$. The yield was enhanced approximately $17 \%$ in the presence of $1.0 \mu \mathrm{mol} \mathrm{NADP}^{+} /(\mathrm{mmol} \mathrm{COBE})$ or more compared to that in the absence of external $\mathrm{NADP}^{+}$, likely because the amount of cofactor in vivo is insufficient to this reaction. Based on cost considerations, the ratio of $\mathrm{NADP}^{+} / \mathrm{COBE}(\mu \mathrm{mol} / \mathrm{mmol})$ was limited to 1.0 . Reaction $\mathrm{pH}$ and temperature play important roles in biotransformation, which can significantly affect the activity and stability of biocatalysts, the speed of substrate molecules motion, and the activation energy of the bioreduction. The optimum temperature of coexpressed E. coli was inconsistent with that of single $B g A D H 3$. This might be explained that the high temperature impact the GDH activity before affect the $B g A D H 3$ activity. The substrate loading was considerably improved with the increased of cell dosage at a fixed S/C (mmol/g DCW) of 150, while the yield was significantly reduced when the cell dosage was too high due to the increased viscosity in the reaction media which might be hinder the molecular transfer between substrate and enzyme [1]. To the best of our knowledge, this is the first report of a preparative-scale highly stereoselective reduction of COBE to $(R)-\mathrm{CHBE}$ by using a newly cloned BgADH3 co-expressed with GDH. From a practical viewpoint, this asymmetric synthesis of $(R)$-CHBE is promising since no example reported to produce $(R)$-CHBE with more than $1200 \mathrm{mmol}$ of in 1 -L reaction system yet (Table 4).

\section{Conclusions}

In summary, a SCR toolbox was constructed in this work through genome hunting and data mining approaches based on bioinformatics analysis of sequence-

Table 4 Comparison of several reported biocatalysts for producing (R)-CHBE

\begin{tabular}{|c|c|c|c|c|c|c|c|}
\hline Enzyme & SSAR & SsALR & CpSADH & BYueD & Gox2036 & LEK & $\mathrm{BgADH} 3$ \\
\hline Family & AKR & AKR & MDR & - & SDR & AKR & SDR \\
\hline Solvent system & water/n-butyl acetate & water & water & water/toluene & water & water & water/octanol \\
\hline Cofactor enzyme & $\mathrm{GDH}$ & $\mathrm{GDH}$ & / & $\mathrm{GDH}$ & $\mathrm{GDH}$ & $\mathrm{GDH}$ & $\mathrm{GDH}$ \\
\hline Cosubstrate & G & G & IPA & G & G & G & G \\
\hline External cofactor & $\mathrm{NADP}^{+}$ & $\mathrm{NADP}^{+}$ & Without & $\mathrm{NADP}^{+}$ & $\operatorname{NAD}(H)$ & Without & $\mathrm{NADP}^{+}$ \\
\hline Substrate loading (mmol) & 91 & 0.61 & 1.525 & 13 & 0.06 & 111 & 1200 \\
\hline Biocatalyst (g) & 2 (wet) & 0.4 (wet) & / & 0.5 (dry) & 0.1 (wet) & 17 (dry) & 8 (dry) \\
\hline Reaction volume $(\mathrm{mL})$ & 50 & 10 & 25 & 20 & 10 & / & 1000 \\
\hline Reaction time (h) & 50 & 10 & 17 & 5 & 24 & 1 & 20 \\
\hline ee of $(R)-\mathrm{CHBE}$ & 91.7 & 99 & 99 & 99.6 & 100 & $>99$ & 99.9 \\
\hline References & [15] & {$[48]$} & [49] & [18] & [14] & [17] & This work \\
\hline
\end{tabular}


similarity with known stereoselective SCR, and further subjected to the asymmetric synthesis of $(R)$-CHBE. The newly cloned BgADH3 from B. gladioli displayed high activity and excellent enantioselectivity toward COBE, and served as a versatile SCR with a broad substrate spectrum converting varied aromatic ketones and ketoesters to the corresponding chiral alcohols with excellent enantiomeric purity ( $>99 \% e e$ ). Furthermore, asymmetric synthesis of $(R)-\mathrm{CHBE}$ was developed by using recombinant $E$. coli cells co-expressing $B g A D H 3$ and GDH. Using substrate fed-batch mode and aqueous/ octanol biphasic system, the decomposition of COBE and its inhibition of the biocatalyst were significantly alleviated. Using the "designer cells", $(R)$-CHBE was produced at a high space-time yield per gram of biomass of $4.47 \mathrm{mmol} \cdot \mathrm{L}^{-1} \cdot \mathrm{h}^{-1} \cdot \mathrm{g} \mathrm{DCW}^{-1}$ and excellent enantiopurity $(99.9 \% e e)$ with the highest substrate total loading of $1200 \mathrm{mmol}$ in 1-L reaction system reported so far. This study allows for the further application of $B g A D H 3$ in the biosynthesis of chiral alcohols, and establishes a preparative scale process for producing $(R)$-CHBE with excellent enantiopurity.

\section{Methods}

\section{Strains, plasmids and chemicals}

The E. coli DH5 $\alpha$ (Tiangen biotech Co., Ltd., Beijing, China) and E. coli BL21 (DE3) (Novagen, Darmstadt, Germany) were selected as hosts in this study. Plasmid pGEM-T (Promega, Beijing, China) and pET28a (Novagen, Darmstadt, Germany) were used for cloning and expression, respectively. Polymerase chain reaction (PCR) mix and restriction endonucleases were purchased from Vazyme (Nanjing, China). Ampicillin and kanamycin were obtained from solarbio (Beijing, China). Streptomycin and IPTG were purchased from Sangon Biotech (Shanghai, China). COBE and $(R)$ CHBE were provided by J\&K Scientific Ltd. (Shanghai, China). All other chemicals were of analytical grade and commercially available.

\section{Expression of SCRs in E. coli cells}

Strain CCTCC M 2012379 was cultivated as described previously [44]. The genomic DNA of this strain was extracted using a FastDNA ${ }^{\circ}$ Spin Kit for Soil (MPBio, Shanghai, China). The genes of SCRs were amplified by PCR using appropriate primers designed according to the putative proteins from B. gladioli BSR3 (Additional file 7: Table S5). Each amplified DNA fragment was inserted into pGEM-T to create pGEM-T-SCR, and digested with restriction endonucleases. The desired fragment was subcloned into linearied pET28a with the same restriction enzyme cutting sites and transformed in E. coli BL21 (DE3). Other SCRs genes were synthesized and transformated in E. coli BL21 (DE3).

\section{Cell growth and enzyme purification}

The recombinant E. coli strains with SCRs were cultivated, induced, and purified as described previously [45]. The protein expression level was verified by SDS-PAGE. The native molecular weight was measured using a Discovery BIO GFC $150(300 \times 7.8 \mathrm{~mm}, 3 \mu \mathrm{m})$ column (Sigma-Aldrich, Shanghai, China) equilibrated with phosphate buffer $(150 \mathrm{mM})$ at $1.0 \mathrm{~mL} / \mathrm{min}$ using cytochrome c (12.4 kDa), ovalbumin (43 kDa), bovine serum albumin $(66 \mathrm{kDa})$, and yeast alcohol dehydrogenase $(150 \mathrm{kDa})$ as standard proteins. Protein concentration was determined using BCA Protein Assay Kit (KeyGEN BioTECH, Nanjing, China) with bovine serum albumin (BSA) as a standard.

\section{Enzyme assays}

Specific activity was detected spectrophotometrically by monitoring the depletion in the absorption of $\mathrm{NAD}(\mathrm{P}) \mathrm{H}$ at $340 \mathrm{~nm}$. One unit (U) of enzymatic activity was defined as $1 \mu \mathrm{mol}$ of $\mathrm{NAD}(\mathrm{P}) \mathrm{H}$ consumed per minute under the assay conditions. Each assay mixture contained COBE $(50 \mathrm{mM})$ and $\mathrm{NAD}(\mathrm{P}) \mathrm{H}(0.5 \mathrm{mM})$ in phosphate buffer $(100 \mathrm{mM}, \mathrm{pH}$ 6.5). The activity was determined after the addition of $\mathrm{NAD}(\mathrm{P}) \mathrm{H}$ for $2 \mathrm{~min}$. The same method was used in all reactions against other substrates.

\section{Characterization of recombinant BgADH3}

Specific activities were evaluated under standard assay conditions using COBE as substrate. The effect of $\mathrm{pH}$ on the activity of $B g \mathrm{ADH} 3$ was assessed within a $\mathrm{pH}$ range of 3.5-10.5, using disodium hydrogen phosphate-citrate buffer (3.5-7.0), phosphate buffer $(6.0-8.0)$, Tris- $\mathrm{HCl}$ buffer (7.5-9.0), and Gly-NaOH buffer (9.0-10.5). The $\mathrm{pH}$ stability was tested by pre-incubating purified $B g$ ADH3 in buffers with different $\mathrm{pH}$ values at $30{ }^{\circ} \mathrm{C}$ for $2 \mathrm{~h}$, and then the residual activity was measured. The non-incubated enzyme was considered as a control. The effect of temperature on the activity was studied by assaying activities at temperatures ranging from $25{ }^{\circ} \mathrm{C}$ to $65{ }^{\circ} \mathrm{C}$. The thermostability was estimated by incubating the purified $B g A D H 3$ in the phosphate buffer $(100 \mathrm{mM}$, $\mathrm{pH} 6.5)$ at $25,35,45,55$, and $65^{\circ} \mathrm{C}$, respectively. Samples were withdrawn per hour and the residual activities were detected. The non-heated enzyme was taken as a control. The effect of metal ions on the activity was evaluated by pre-incubating recombinant $B g A D H 3$ in the presence of $\mathrm{Fe}^{2+}, \mathrm{Ni}^{2+}, \mathrm{Fe}^{3+}, \mathrm{Ca}^{2+}, \mathrm{Ba}^{2+}, \mathrm{Cu}^{2+}, \mathrm{Mn}^{2+}, \mathrm{Zn}^{2+}$, $\mathrm{Co}^{2+}, \mathrm{Mg}^{2+}, \mathrm{Ag}^{+}$, and EDTA $(2 \mathrm{mM})$ at $30{ }^{\circ} \mathrm{C}$ for $30 \mathrm{~min}$. Measurements of kinetic parameters were done by altering the concentration of NADH or NADPH (0.01$0.5 \mathrm{mM})$ at a constant COBE concentration $(50 \mathrm{mM})$, and were calculated through nonlinear regression of the Michaelis-Menten equation. The influence of 
organic solvents on the activity was assessed by adding hydrophobic solvents $(50 \%, \mathrm{v} / \mathrm{v})$, including tetrahydrofuran (THF), ethyl acetate, $n$-butanol, tert-amylalcohol, MTBE, dichloromethane, butyl acetate, toluene, octanol, cyclohexane, $n$-hexane, $n$-heptane, and iso-octane. Stability was determined by measuring the residual activity after incubation with organic solvents at $30{ }^{\circ} \mathrm{C}$ for $30 \mathrm{~min}$. All assays were performed in triplicate.

\section{Stereoselectivity}

The stereoselectivity of $B g A D H 3$ was estimated by testing the asymmetric reduction of aryl ketones and ketoesters using glucose as the cosubstrate. Each reaction mixture was comprised of phosphate buffer $(100 \mathrm{mM}$, $\mathrm{pH}$ 6.5), substrate in DMSO (50 mM, $5 \% \mathrm{v} / \mathrm{v})$, NADPH (0.05 mM), glucose $(278 \mathrm{mM}), \mathrm{GDH}\left(0.1 \mathrm{mg} \mathrm{mL}^{-1}\right)$, and purified $B g A D H 3\left(0.1 \mathrm{mg} \mathrm{mL}^{-1}\right)$ in a total volume of $0.5 \mathrm{~mL}$, and proceeded at $40{ }^{\circ} \mathrm{C}$ for $6 \mathrm{~h}$. Reaction mixture without recombinant $\mathrm{BgADH} 3$ was used as the control. After complete of the reaction, each biotransformation solution was extracted with ethyl acetate. The ee or de values of products were determined by GC or HPLC analysis.

\section{Co-expression of BgADH3 and GDH genes}

The pGEM-T-GDH was constructed as previously reported [9], and digested with Nde I and Xho I restriction enzymes. The fragment of interest was induced into the Nde I/Xho I site (MCSI) of plasmid pCDFDuet-1 to afford recombinant pCDFDuet-1-GDH vector. Subsequently, the $B g A D H 3$ gene cut from pGEM-T-BgADH3 with Nco I and Hind III was ligated to the Nco I/Hind III site (MCSII) of pCDFDuet-1-GDH, leading to the final recombinant plasmid pCDFDuet-1-BgADH3-GDH harboring $B g A D H 3$ and GDH genes. The resulting coexpressed plasmid was further transformed into $E$. coli BL21 (DE3) and grown in LB medium containing streptomycin $\left(50 \mu \mathrm{g} \mathrm{mL}^{-1}\right)$. The expression levels of this recombinant genes were verified by SDS-PAGE.

\section{Efficient biosynthesis of (R)-CHBE in aqueous-organic solvent system \\ Screening of organic solvents}

Different organic solvents were evaluated in the asymmetric synthesis of $(R)$-CHBE using co-expression $E$. coli/pCDFDuet-1-BgADH3-GDH at $40{ }^{\circ} \mathrm{C}$ for $6 \mathrm{~h}$ by mixing an equal volume of the tested solvents with $10 \mathrm{~mL}$ phosphate buffer $(100 \mathrm{mM}, \mathrm{pH}$ 6.5) consisted of COBE $(6 \mathrm{mmol})$, glucose $(12 \mathrm{mmol}), \mathrm{NADP}^{+}(6 \mu \mathrm{mol})$, and sonicated co-expressed E. coli cells (0.04 g DCW). The $\mathrm{pH}$ of the reaction mixture was monitored at 6.5 with $2 \mathrm{M} \mathrm{NaOH}$ during reaction. The ee and quantity of COBE and $(R)$-CHBE were determined by GC [2].

\section{Optimization of reaction conditions}

Several reaction parameters (e.g., glucose concentration, $\mathrm{NADP}^{+}$concentration, reaction $\mathrm{pH}$, reaction temperature, cell dosage and substrate loading, etc.) affected the biotransformation were assessed by adding different concentrations of glucose (1-9 mmol glucose/(mmol COBE)), $\mathrm{NADP}^{+}(0-2 \mu \mathrm{mol} /(\mathrm{mmol} \mathrm{COBE}))$, cell dosage $(0.02-$ $0.1 \mathrm{~g} \mathrm{DCW})$, and COBE (6-48 mmol) in $10 \mathrm{~mL}$ phosphate buffer mixed with an equal volume of octanol. Unless otherwise stated, each assay was stirred at $40{ }^{\circ} \mathrm{C}$ for $6 \mathrm{~h}$. The effects of reaction temperature and $\mathrm{pH}$ on the biosynthesis were performed at various temperatures $\left(25-60{ }^{\circ} \mathrm{C}\right)$ and different pHs (4.0-9.0).

\section{Substrate fed-batch strategy and preparative scale}

Substrate fed-batch was carried out in 1-L reaction system, which comprising phosphate buffer (100 mM, $\mathrm{pH}$ 6.5), COBE (600 mmol), glucose $(1800 \mathrm{mmol})$, and sonicated E. coli/pCDFDuet-1-BgADH3-GDH (8 g DCW), in a final volume of $0.5 \mathrm{~L}$, was mixed with an equal volume of octanol in a bioreactor with two electrodes for monitoring the temperature and $\mathrm{pH}$. The resulting mixture was stirred at $200 \mathrm{rpm}$ for $20 \mathrm{~h}$. The temperature was maintained at $30{ }^{\circ} \mathrm{C}$ and the $\mathrm{pH}$ was adjusted to 6.5 with $2 \mathrm{M} \mathrm{NaOH}$ during the reaction. COBE $(300 \mathrm{mmol})$ and glucose $(900 \mathrm{mmol})$ were added to the reaction mixture at 6 and $12 \mathrm{~h}$, respectively. After reaction, the two layers were separated and the aqueous layer was extracted twice with ethyl acetate. The extracted layers were combined with the original organic layer, washed with $\mathrm{NaHCO}_{3}$, and dried by anhydrous $\mathrm{Na}_{2} \mathrm{SO}_{4}$. The obtained solvent was evaporated under vacuum, offering the final product as oily liquid. High-resolution mass spectrum (MS) was obtained on an Agilent 6210 TOF LC/MS system (Palo Alto, CA, USA). Nuclear Magnetic Resonance (NMR) spectra of the final product were performed on Bruker AVANCE III (Bruker, Switzerland) spectrometer. Polarimetry were carried on Rudolph Autopol IV polarimeter (Rudolph, USA) using the sodium D line $(589 \mathrm{~nm})$ at $25^{\circ} \mathrm{C}$.

\section{Additional files}

Additional file 1: Table S1. Results of screening microorganisms for direct asymmetric reduction of ethyl 4-chloro-3-oxobutanoate. (DOCX $24 \mathrm{~kb}$ )

Additional file 2: Table S2. Results of screening stereoselective carbonyl reductases for direct asymmetric reduction of ethyl 4-chloro-3-oxobutanoate. (DOCX $18 \mathrm{~kb}$ )

Additional file 3: Figure S1. Amino acid sequence alignments of shortchain alcohol dehydrogenase/reductase using ESPript 3.0. Sequences are Burkholderia gladioli from this study (BgADH3, GenBank Accession No. AEA63541), Gluconobacter oxydans 621H (Gox2036, GenBank Accession No. AAW61772.1), Lactobacillus brevis ( $L b A D H$, GeneBank Accession No. CAD66648.1), Salmonella enteric (Ygha, PDB: 3R3S_A), and Bacillus anthracis (BaADH, PDB: 3130_A). The cofactor-binding motifs in the SDRs, TGXXXGXG and $P G$, are highlighted in orange and triangle while the residues of the catalytic tetrad (N, S, Y, and K) are highlighted in green. (DOCX $212 \mathrm{~kb}$ ) 
Additional file 4: Table S3. Effect of metal ions on the activity of recombinant BgADH3. (DOCX $17 \mathrm{~kb})$

Additional file 5: Table S4. GC and HPLC analysis of the ee or de values of products. (DOCX $19 \mathrm{~kb}$ )

Additional file 6: Figure S2. ${ }^{1} \mathrm{H}$ NMR of the isolated $(R)-\mathrm{CHBE}$ $\left(500 \mathrm{MHz}_{1} \mathrm{CDCl}_{3}\right)$. Figures S3. ${ }^{13} \mathrm{C}$ NMR of the isolated $(R)-\mathrm{CHBE}$ (126 MHz, CDCl $)$. (DOCX $1122 \mathrm{~kb})$

Additional file 7: Table S5. Primers from Burkholderia gladioli CCTCC M 2012379 for PCR amplification. (DOCX 18 kb)

\section{Abbreviations}

(R)-CHBE: Ethyl (R)-4-chloro-3-hydroxybutyrate; $\mathrm{CH}_{2} \mathrm{Cl}_{2}$ : Dichloromethane; COBE: Ethyl 4-chloro-3-oxobutanoate; E. coli: Escherichia coli; GDH: Glucose dehydrogenase; MS: Mass spectrum; MTBE: Methyl tert-butyl ether; NMR: Nuclear magnetic resonance; SCRs: Stereoselective carbonyl reductases; SDS-PAGE: Sodium dodecyl sulfate polyacrylamide gel electrophoresis; THF: Tetrahydrofuran

\section{Acknowledgements}

We would like to acknowledge the Analysis and Testing Center of Zhejiang University of Technology for offering the MS and NMR assistance.

\section{Funding}

This study was financially supported by the National Natural Science Foundation of China (no. 21672190), and Natural Science Foundation of Zhejiang Province, China (No. R3110155)

\section{Availability of data and materials}

The datasets supporting the conclusions of this article are included within the manuscript and its additional files.

\section{Author's contributions}

CX participated in the design and performed the experiments in the study, and drafted the manuscript. LZQ designed the experiments and revised the manuscript. LCP performed gene cloning, expression and helped to draft this manuscript. ZYG conceived, designed and supervised the experiments, is a corresponding author. All authors have read and approved the manuscript.

\section{Competing interests}

The authors declare that they have no competing interests.

\section{Consent for publication}

Not applicable.

\section{Ethics approval and consent to participate}

Not applicable.

Received: 4 March 2016 Accepted: 13 October 2016

Published online: 18 October 2016

\section{References}

1. He YC, Tao ZC, Zhang X, Yang ZX, Xu JH. Highly efficient synthesis of ethyl (S)4-chloro-3-hydroxybutanoate and its derivatives by a robust NADH-dependent reductase from E-coli CCZU-K14. Bioresour Technol. 2014;161:461-4.

2. You ZY, Liu ZQ, Zheng YG. Characterization of a newly synthesized carbonyl reductase and construction of a biocatalytic process for the synthesis of ethyl (S)-4-chloro-3-hydroxybutanoate with high space-time yield. Appl Microbiol Biotechnol. 2014;98(4):1671-80.

3. Chen X, Liu ZQ, Huang JF, Lin CP, Zheng YG. Asymmetric synthesis of optically active methyl-2-benzamido-methyl-3-hydroxy-butyrate by robust short-chain alcohol dehydrogenases from Burkholderia gladioli. Chem Commun. 2015;51(61):12328-31.

4. Applegate GA, Cheloha RW, Nelson DL, Berkowitz DB. A new dehydrogenase from Clostridium acetobutylicum for asymmetric synthesis: dynamic reductive kinetic resolution entry into the Taxotere side chain. Chem Commun. 2011; 47(8):2420-2.

5. Patel RN. Biocatalysis: Synthesis of key intermediates for development of pharmaceuticals. ACS Catal. 2011;1(9):1056-74.
6. Marzi M, Minetti P, Moretti G, Tinti MO, De Angelis F. Efficient enantioselective synthesis of (R)-(-)-carnitine from glycerol. J Org Chem. 2000;65(20):6766-9.

7. Wang GJ, Hollingsworth RI. Synthetic routes to L-carnitine and L-gammaamino-beta-hydroxybutyric acid from (S)-3-hydroxybutyrolactone by functional group priority switching. Tetrahedron Asymmetry. 1999; 10(10):1895-901.

8. Matsuyama A, Yamamoto H, Kobayashi Y. Practical application of recombinant whole-cell biocatalysts for the manufacturing of pharmaceutical intermediates such as chiral alcohols. Org Process Res Dev. 2002;6(4):558-61.

9. Liu ZQ, Ye JJ, Shen ZY, Hong HB, Yan JB, Lin Y, Chen ZX, Zheng YG, Shen YC. Upscale production of ethyl (S)-4-chloro-3-hydroxybutanoate by using carbonyl reductase coupled with glucose dehydrogenase in aqueousorganic solvent system. Appl Microbiol Biotechnol. 2015;99(5):2119-29.

10. Nie Y, Xiao R, Xu Y, Montelione GT. Novel anti-Prelog stereospecific carbonyl reductases from Candida parapsilosis for asymmetric reduction of prochiral ketones. Org Biomol Chem. 2011;9(11):4070-8.

11. Pan J, Zheng GW, Ye Q, Xu JH. Optimization and scale-up of a bioreduction process for preparation of ethyl (S)-4-chloro-3-hydroxybutanoate. Org Process Res Dev. 2014;18(6):739-43.

12. Ye Q, Ouyang PK, Ying HJ. A review-biosynthesis of optically pure ethyl (S)4-chloro-3-hydroxybutanoate ester: recent advances and future perspectives. Appl Microbiol Biotechnol. 2011;89(3):513-22.

13. Srivastava G, Pal M, Kaur S, Jolly RS. A highly efficient designer cell for enantioselective reduction of ketones. Catal Sci Technol. 2015;5(1):105-8.

14. Liu X, Chen R, Yang ZW, Wang JL, Lin JP, Wei DZ. Characterization of a putative stereoselective oxidoreductase from Gluconobacter oxydans and its application in producing ethyl $(R)$-4-chloro-3-hydroxybutanoate ester. Mol Biotechnol. 2014;56(4):285-95.

15. Kataoka M, Yamamoto K, Kawabata H, Wada M, Kita K, Yanase H, Shimizu S. Stereoselective reduction of ethyl 4-chloro-3-oxobutanoate by Escherichia coli transformant cells coexpressing the aldehyde reductase and glucose dehydrogenase genes. Appl Microbiol Biotechnol. 1999;51(4):486-90.

16. Ning C, Su E, Wei D. Characterization and identification of three novel aldoketo reductases from Lodderomyces elongisporus for reducing ethyl 4chloroacetoacetate. Arch Biochem Biophys. 2014:564:219-28.

17. Wang Q, Ye T, Ma Z, Chen R, Xie T, Yin X. Characterization and site-directed mutation of a novel aldo-keto reductase from Lodderomyces elongisporus NRRL YB-4239 with high production rate of ethyl (R)-4-chloro-3hydroxybutanoate. J Ind Microbiol Biotechnol. 2014;41(11):1609-16.

18. Ni Y, Li CX, Wang LJ, Zhang J, Xu JH. Highly stereoselective reduction of prochiral ketones by a bacterial reductase coupled with cofactor regeneration. Org Biomol Chem. 2011;9(15):5463-8.

19. Yang WJ, Cao H, Xu L, Zhang HJ, Yan YJ. A novel eurythermic and thermostale lipase LipM from Pseudomonas moraviensis M9 and its application in the partial hydrolysis of algal oil. BMC Biotechnol. 2015;15:94.

20. Musa MM, Phillips RS. Recent advances in alcohol dehydrogenase-catalyzed asymmetric production of hydrophobic alcohols. Catal Sci Technol. 2011;1(8):1311-23.

21. Ni Y, Xu JH. Biocatalytic ketone reduction: a green and efficient access to enantiopure alcohols. Biotechnol Adv. 2012;30(6):1279-88.

22. Liang JJ, Zhang ML, Ding M, Mai ZM, Wu SX, Du Y, Feng JX. Alcohol dehydrogenases from Kluyveromyces marxianus: heterologous expression in Escherichia coli and biochemical characterization. BMC Biotechnol. 2014;14:45

23. Mandaui AM, Mandavi R, Kolahi S, Zemestani M, Vatankhah AM. L-Carnitine supplementation improved clinical status without changing oxidative stress and lipid profile in women with knee osteoarthritis. Nutr Res. 2015;35(8):707-15.

24. Filling C, Berndt KD, Benach J, Knapp S, Prozorovski T, Nordling E, Ladenstein $\mathrm{R}$, Jornvall $H$, Oppermann U. Critical residues for structure and catalysis in short-chain dehydrogenases/reductases. J Biol Chem. 2002;277(28):25677-84.

25. Niefind K, Müller J, Riebel B, Hummel W, Schomburg D. The crystal structure of $R$-specific alcohol dehydrogenase from Lactobacillus brevis suggests the structural basis of its metal dependency. J Mol Biol. 2003;327(2):317-28.

26. Chen $X H$, Wei $P$, Wang XT, Zong MH, Lou WY. A novel carbonyl reductase with anti-Prelog stereospecificity from Acetobacter sp CCTCC M209061: Purification and characterization. PLoS One. 2014;9(4), e94543.

27. Peng GJ, Kuan YC, Chou HY, Fu TK, Lin JS, Hsu WH, Yang MT. Stereoselective synthesis of $(R)$-phenylephrine using recombinant Escherichia coli cells 
expressing a novel short-chain dehydrogenase/reductase gene from Serratia marcescens BCRC 10948. J Biotechnol. 2014;170:6-9.

28. Musa MM, Ziegelmann-Fjeld KI, Vieille C, Zeikus JG, Phillips RS. Xerogel-encapsulated W110A secondary alcohol dehydrogenase from thermoanaerobacter ethanolicus performs asymmetric reduction of hydrophobic ketones in organic solvents. Angew Chem Int Ed. 2007;46(17):3091-4.

29. Singh M, Singh S, Deshaboina S, Krishnen H, Lloyd R, Holt-Tiffin K, Bhattacharya A, Bandichhor R. Asymmetric reduction of a key intermediate of eslicarbazepine acetate using whole cell biotransformation in a biphasic medium. Catal Sci Technol. 2012;2(8):1602-5.

30. Klibanov AM. Asymmetric enzymatic oxidoreductions in organic solvents. Curr Opin Biotechnol. 2003;14(4):427-31.

31. Karabec M, Lyskowski A, Tauber KC, Steinkellner G, Kroutil W, Grogan G, Gruber K. Structural insights into substrate specificity and solvent tolerance in alcohol dehydrogenase ADH-'A' from Rhodococcus ruber DSM 44541. Chem Commun. 2010;46(34):6314-6

32. Kara S, Spickermann D, Weckbecker A, Leggewie C, Arends IWCE, Hollmann F. Bioreductions catalyzed by an alcohol dehydrogenase in non-aqueous media. ChemCatChem. 2014;6(4):973-6.

33. Liu ZQ, Zhou LM, Liu P, Baker PJ, Liu SS, Xue YP, Xu M, Zheng YG. Efficient two-step chemo-enzymatic synthesis of all-trans-retinyl palmitate with high substrate concentration and product yield. Appl Microbiol Biotechnol. 2015; 99(21):8891-902.

34. Klibanov AM. Improving enzymes by using them in organic solvents. Nature. 2001:409(6817):241-6.

35. Wu X, Zhang C, Orita I, Imanaka T, Fukui T, Xing XH. Thermostable alcohol dehydrogenase from Thermococcus kodakarensis KOD1 for enantioselective bioconversion of aromatic secondary alcohols. Appl Environ Microbiol. 2013: 79(7):2209-17.

36. Villela M, Stillger T, Muller M, Liese A, Wandrey C. Is $\log P$ a convenient criterion to guide the choice of solvents for biphasic enzymatic reactions? Angew Chem Int Ed. 2003;42(26):2993-6.

37. Zhu DM, Rios BE, Rozzell JD, Hua L. Evaluation of substituent effects on activity and enantioselectivity in the enzymatic reduction of aryl ketones. Tetrahedron Asymmetry. 2005;16(8):1541-6.

38. Kara S, Schrittwieser JH, Hollmann F, Ansorge-Schumacher MB. Recent trends and novel concepts in cofactor-dependent biotransformations. Appl Microbiol Biotechnol. 2014;98(4):1517-29.

39. Rodriguez C, Lavandera I, Gotor V. Recent advances in cofactor regeneration systems applied to biocatalyzed oxidative processes. Curr Org Chem. 2012; 16(21):2525-41.

40. Wu H, Tian CY, Song XK, Liu C, Yang D, Jiang ZY. Methods for the regeneration of nicotinamide coenzymes. Green Chem. 2013;15(7):1773-89.

41. Groger H, Chamouleau F, Orologas N, Rollmann C, Drauz K, Hummel W, Weckbecker A, May O. Enantioselective reduction of ketones with "Designer cells" at high substrate concentrations: Highly efficient access to functionalized optically active alcohols. Angew Chem Int Ed. 2006;45(34):5677-81.

42. Ma HM, Yang LL, Ni Y, Zhang J, Li CX, Zheng GW, Yang HY, Xu JH. Stereospecific reduction of methyl o-chlorobenzoylformate at $300 \mathrm{~g} \mathrm{~L} \mathrm{~L}^{-1}$ without additional cofactor using a carbonyl reductase mined from Candida glabrata. Adv Synth Catal. 2012;354(9):1765-72.

43. Shen ND, Ni Y, Ma HM, Wang LJ, Li CX, Zheng GW, Zhang J, Xu JH. Efficient synthesis of a chiral precursor for Angiotensin-Converting Enzyme (ACE) inhibitors in high space-time yield by a new reductase without external cofactors. Org Lett. 2012;14(8):1982-5.

44. Chen X, Zheng YG, Liu ZQ, Sun LH. Stereoselective determination of 2-benzamidomethyl-3-oxobutanoate and methyl-2-benzoylamide-3hydroxybutanoate by chiral high-performance liquid chromatography in biotransformation. J Chromatogr B. 2015;974:57-64.

45. Liu ZQ, Baker PJ, Cheng F, Xue YP, Zheng YG, Shen YC. Screening and improving the recombinant nitrilases and application in botransformation of iminodiacetonitrile to iminodiacetic acid. PLoS One. 2013;8(6), e67197.

46. Wang $L$, Li CX, Ni Y, Zhang J, Liu X, Xu JH. Highly efficient synthesis of chiral alcohols with a novel NADH-dependent reductase from Streptomyces coelicolor. Bioresour Technol. 2011;102(14):7023-8.

47. Ye Q, Cao H, Zang GL, Mi L, Yan M, Wang Y, Zhang YY, Li XM, Li J, Xu L, et al. Biocatalytic synthesis of (S)-4-chloro-3-hydroxybutanoate ethyl ester using a recombinant whole-cell catalyst. Appl Microbiol Biotechnol. 2010;88(6): $1277-85$.
48. Jing K, Xu Z, Liu Y, Jiang X, Peng L, Cen P. Efficient production of recombinant aldehyde reductase and its application for asymmetric reduction of ethyl 4chloro-3-oxobutanoate to ethyl (R)-4-chloro-3-hydroxybutanoate. Prep Biochem Biotechnol. 2005;35(3):203-15.

49. Yamamoto H, Matsuyama A, Kobayashi Y. Synthesis of ethyl (R)-4-chloro-3hydroxybutanoate with recombinant Escherichia coli cells expressing (S)specific secondary alcohol dehydrogenase. Biosci Biotechnol Biochem. 2002;66(2):481-3.

\section{Submit your next manuscript to BioMed Central and we will help you at every step:}

- We accept pre-submission inquiries

- Our selector tool helps you to find the most relevant journal

- We provide round the clock customer support

- Convenient online submission

- Thorough peer review

- Inclusion in PubMed and all major indexing services

- Maximum visibility for your research

Submit your manuscript at www.biomedcentral.com/submit
Biomed Central 